\title{
Challenges Associated with the Handling of Tomatoes in the Ho Central Market
}

Grace Denny Doku (Corresponding author)

Department of Agro Enterprise Development, Faculty of Applied Sciences and Technology

Ho Technical University, P. O. Box HP 217, Ho, Ghana

E-mail: avliaman@yahoo.com

Margaret Aba Sam Hagan

Department of Agropreneurship, Faculty of Entrepreneurship and Enterprise Development

Kumasi Technical University, Kumasi, Ghana

E-mail: aba_hagan13@yahoo.com

Joyce Mamle Mawusi Obubuafo

Department of Agro Enterprise Development, Faculty of Applied Sciences and Technology

Ho Technical University, P. O. Box HP 217, Ho, Ghana

E-mail: mamlejo1@yahoo.com

Received: March 21, 2020 Accepted: April 18, 2020 Published: May 6, 2020

doi:10.5296/ber.v10i2.16984ＵRL: https://doi.org/10.5296/ber.v10i2.16984

\begin{abstract}
The study sought to evaluate tomato handling processes and their associated challenges faced by venders in the Ho Central Market. Data was generated by randomly sampling one hundred (100) tomato vendors within the study area. Descriptive statistics was used to analyze the data collected from the respondents. The study revealed handling methods adopted by the tomato vendors in the Ho Central Market. These methods included storing the fruits in boxes as well as spreading them on the floor in the warehouses in an orderly manner. According to the respondents these practices were adopted to ensure long life span of the tomatoes. Another handling method revealed by the study involved displaying the fruits on trays during hawking. This practice was to attract customers and to improve sales or patronage. The study
\end{abstract}


recommended that vendors should be educated on modern and hygienic ways of handling their wares in order to enhance the fruits' life span. Also, storage facilities should be made available and affordable by the authorities in charge of the Ho Central Market for proper storage of perishable commodities to keep them hygienic and also enhance their life span.

Keywords: Tomatoes, Ho Central market, Perishable commodities

\section{Introduction}

The role of agriculture in most developing countries cannot be over-emphasized as it is the backbone of many developing economies. The food and agriculture industry plays a major role in Ghana's economy. The marketability and proper handling of agricultural produce can ensure agricultural productivity. Aminu (2009) pointed out that marketing of vegetables does not require much capital but needs some form of experience, connections or partnerships and specialization in its marketing, According to Haruna et al, (2012), also, efficient marketing links sellers and buyers in reacting to current situations in supply and demand and plays a role in stimulating consumption. The points stated by the above cited authors are important ingredients of economic development thus making Agricultural marketing an important activity in the flow of products and services from the production point to the ultimate consumer.

Tomato as a vegetable plays an important role in a healthy diets as a fruit rich in nutrients such as carotenoids, lycopene, beta-carotene and gamma-carotene, phytoene as well as several minor carotenoids (Beecher, 1998). The consumption of tomatoes help in the fight against diseases such as cancer, heart diseases and premature ageing. Lycopene for instance helps reduce metabolic diseases in the body (Fenni et. al., 2017).

Tomato forms an essential part of human food and can be consumed raw or serve as condiment in sauces and some drinks. It is a prominent protective food and a vital ingredient in foods consumed in Ghana as evidently present in most Ghanaian dishes (Tambo and Gbemu, 2010). Tomatoes are thus common in most diet to the extent that a meal is not complete without it and are usually preferred in the fresh state (Drechel, 2010). This makes tomato significant for the healthy growth of citizens in an economy (Alam, 2007; Beecher, 1998). However, tomatoes are highly perishable in the raw state and require proper handling in order to get to consumers in good conditions. Urban and per-urban production system in several African cities supply about 50\%-90\% of fresh vegetables including tomatoes (Cofie, 2003) but lack of infrastructure in these areas make handling of produce a challenge. According to Obuobie et al, (2013), in Ghana, vegetables production and marketing provide the people with employment opportunities, contributing significantly to livelihoods and food security. However, poor handling of vegetables by vendors reduce their durability and quality. In order for tomato venders to maximize profit, proper attention must be given to proper handling of the fruits to reduce post-harvest losses.

Improving the production capacities of tomato farmers has been the focus of the stakeholders in the tomato industry in Ghana. Tomato venders in selling their wares go through a whole lot of experiences and challenges in the marketing and handling of their wares ranging from the 
storage of their goods to the packaging of the goods in order for it to be ready for the market. Some tomato traders may not have the required postharvest skills for prolonging the shelf life of tomatoes in commercial quantities. Since fresh tomatoes are highly perishable in nature, vendors face a lot of challenges in the marketing and handling of their produce. It is therefore very vital for vendors to market their produce as quickly as possible since it is perishable and delay in its market and improper handling might result in the vendor encountering heavy losses. The improper handling of tomatoes affects their quality, safety and marketability. There is therefore the need to device the best ways to handle and market tomatoes in the Ho market by venders in order to provide consumers with quality and healthy supplies.

There are limited studies on challenges facing marketers (traders) in the handling and marketing of tomatoes in the Ho market in Ghana. This study therefore seeks to fill the gap in knowledge.

The main objective of the study is to assess the challenges associated with the handling and marketing of tomatoes in the Ho market.

\section{Literature Review}

Tomato (Solanum lycopersicum), which is of the Nightshade family (Solanaceae) is a red edible fruit (online family doctor.com, 2011). The crop which is the third economically most important crop family, is also the most valuable of all crop species in terms of agricultural utility(van der Hoevenet al. 2002). Tomato is used to prepare soups, juices and sauces, ketchups, purees and paste. The crop is also produced on commercial bases to earn foreign exchange to the producer countries through exportation (Hussaini et al., 2011; Singh, 2004). Tomatoes are very delicate and very perishable and if poorly handled and transported, they can be highly susceptible to mechanical damage (Bani, 2006). Kitinoja and Gorny (2009) have recommended that handlers of fresh tomatoes in the markets should avoid rough handling of the vegetables and also minimize the number of handling steps. The authors also recommend the adherence of the temperature and relative humidity management requirement for the crop. Non-uniform containers of tomatoes should also be packed in such a way to prevent collapse of weaker packages (Kitinoja and Gorny, 2009).

Tomato is a rich source of minerals, vitamins and organic acids; the fruit contains $3-4 \%$ total sugar, $4-7 \%$ total solids, $15-30 \mathrm{mg} / 100 \mathrm{~g}$ ascorbic acid, $7.5-10 \mathrm{mg} / 100 \mathrm{ml}$ treatable acidity and $20-50 \mathrm{mg} / 100 \mathrm{~g}$ fruit weight of lycopene.

Tomato fruit has varied physical or visible characteristics which are important for fresh market and processing values. The varied characteristics include shape, size, color, flesh thickness, number of locules, blossom end shape and fruit quality. It may be a globe shape (Marglobe), oval or flattened (Marmande), and pear shaped (Roma VF). These shapes may affect the vegetable's acceptability in the local market, quality, and storability.

\subsection{Concept of Vegetable Marketing}

The term "Marketing" has several concepts. Marketing entails finding out what your customers want and supplying it to them at a profit (Dixie, 2005).Per this definition, 
marketing has to be customer oriented and also provide farmers, transporters, traders, processors, etc. with a profit to enable them stay in business. Marketing as a process identifies buyers, understand what products and / or services they want then supplies it to them. That is, delivering the right products at the right time. It also includes making enough profit to continue to operate vegetable production and trade. Marketing has influence on income distribution, food security, and other important development objectives.

In spite of the importance of marketing, it is given little or no attention in the developing countries.

According to Ministry of Trade and Industry (2007), transaction costs and other causes of market imperfections could reduce the participation of farm households in different markets in spite of the fact that markets are very important in the agricultural commercialization process. The availability of physical markets does not necessarily translate into market accessibility by some farm households. Farm households faced with such situations may tend to choose crops that can easily be sold at the accessible markets. This is usually, associated with households producing perishable crops like tomato. Vegetables and other crops that have seasonal production cycles directly influence their marketing. Such crops have limited period of harvest and more or less a year-round demand. The cultural and religious set up of the society, in some cases, also renders demand to be seasonal. This situation is made worse where there is lack of facilities to store the goods.

To improve vegetable marketing, better packaging, handling, and transport, sorting by quality, extending the market season and leveling out gluts and shortages by market delivery planning and storage, developing new markets, installation of refrigerated transport and processing equipment, and establishing marketing enterprises are some measures commonly recommended.

\subsection{Handling of Tomatoes}

There is a direct link between postharvest handling of fresh vegetables and its shelf life, according to Kitinoja and Gorny (2009). The authors stated that, the handling of tomatoes starts from harvesting and that postharvest losses as a result of poor handling of the vegetable range of $20 \%$ to $50 \%$ in developing countries. The report traces the causes of the losses to the field, during transport and marketing. Losses also may occur along the long chain from the producer to the consumer. Losses of fresh tomato may occur at different stages along the value chain such as the stages of production, sorting, packaging, storage, transport and marketing.

A study on the assessment of losses of tomatoes from Bolgatanga to Accra by Bani (2006) reported as much as $20 \%$ losses along the route alone. Postharvest losses of horticultural produce are a major concern which needs to be addressed. They can be caused by a wide variety of factors, ranging from growing conditions to handling at retail level. Insects can also be a source of postharvest losses of fresh tomatoes. According to Hurst (1993), insects do not destroy tomatoes by consuming large quantities of it, but once they damage the product, further deterioration results from microbial invasion. 


\subsection{Marketing of Tomatoes}

Agricultural marketing involves all the activities associated with the flow of agricultural products and services from the point of production to the ultimate consumers. It includes all that happens to farm produce when they leave the farm gate such as making decision, taking actions and bearing the responsibility of the action. Agricultural marketing also includes all processes that take place from when the farmer plans to meet specified demands and market prospects to when the produce finally gets it to the consumers (Haruna, 2012).

Aminu (2009) reported that marketing of vegetable crops does not require much capital but it does require experience and good rapport with the commission agents and farmers. Olukosi and Isitor (2004) have also indicated that the task of marketing consists of moving of goods from producers to consumers. Farm production effort designed towards the realization of desirable goals through the provision of time, place, and possession and form utilities is expected to be complemented by a well-functioning and well-developed marketing system. There are several relationship and arrangements for the production and the marketing system of tomato which are based on structure conduct-relationship paradigms at each level of marketing from the producers to the consumers. According to Orzolek (2006), wholesale markets, cooperatives, local retailers, roadside stands, pick-your-own operations, and processing firms are the basic marketing alternatives available to the tomato grower.

Tomatoes can be marketed either at wholesale or retail levels, on the farm, at the farm gate, locally or internationally (through exports to other countries). The postharvest handling step taken in handling fresh tomatoes affords one the chance to make more profits when deciding how to market the fresh and processed produce as reported by Kitinoja and Gorny (2009). The local traders sell their vegetables (tomatoes) in village markets, either directly to consumers or through village retailers. Urban traders, unlike their local counterparts, purchase tomatoes in rural markets directly from the farmers or retailers and sell in urban centers. Retailers are the link between wholesalers and final consumers

\section{Methodology}

The study was carried out in the Volta Region of Ghana, specifically Ho municipality. Ho is the capital city of the Ho Municipality and the Volta Region of Ghana. Ho lies between latitude 6 degrees $201 \mathrm{~N}$ and60degrees $551 \mathrm{~N}$ and longitudes 0 degrees $121 \mathrm{E}$ and 0 degrees $531 \mathrm{E}$ and covers an area of 11.65 square kilometers. Generally, mean monthly temperatures range between $220 \mathrm{C}$ and $320 \mathrm{C}$ while annual mean temperature ranges from $16.50 \mathrm{C}$ to 37.80 C. The rainfall pattern is characterized by two rainy seasons referred to as the major and the minor seasons. The major season is from March to June while the minor is from August to November. Further, it lies between Mount Adaklu and Mount Galenkui or Togo Atakora Range. It has a population of about 96,213. Ho has a lively and huge open market that attracts people from all over the Volta Region and migrants from other parts of Ghana.

Data for the study was collected from both primary and secondary sources. In all 100 respondents were sampled for the study. Primary data was collected using a well-structured questionnaire. The respondents were asked to rate the challenges in terms of handling of their 
goods according to their level of importance attached to them using the Likert of Strongly Disagree (SD), Disagree (D), Quite Agree (QA), Agree(A) and Strongly Agree (SA).The data collected was compiled, sorted, edited, classified, and coded into a coding sheet and analyzed using a computerized data analysis package known as SPSS version 20 (Statistical Package for Social Science). Both descriptive and inferential statistics was computed.

\section{Results and Discussion}

\subsection{Socio-Demographic and General Background of Respondents}

Descriptive statistics was used to analyze the data on the distribution of research variables. In the section A of the challenges associated with the handling of tomatoes by vendors in the Ho market, the frequencies distribution was determined on the following categorical variables of Sex, Age range, Nationality and the Level of education of the respondents.

Table 1. Socio Demographic Characteristics of the Respondents

\begin{tabular}{|l|l|l|l|}
\hline Variable & Sub-level & Frequency & Percentages \\
\hline Sex & Male & 26 & 26.0 \\
\hline & Female & 74 & 74.0 \\
\hline Age & $18-24$ & 22 & 22.0 \\
\hline & $25-40$ & 68 & 68.0 \\
\hline & 41 and above & 9 & 9.0 \\
\hline Nationality & Missing & 1 & 1.0 \\
\hline & Ghanaian & 92 & 92.0 \\
\hline & Non-Ghanaian & 7 & 7.0 \\
\hline Educational Level & Missing & 1 & 1.0 \\
\hline & None & 12 & 12.0 \\
\hline & Primary & 11 & 11.0 \\
\hline & JHS/JSS & 53 & 53.0 \\
\hline & Middle School & 23 & 23.0 \\
\hline & Missing System & 1 & 1.0 \\
\hline
\end{tabular}

Source: Survey 2018

Table 1 above depicts the sex distribution of the 100 respondents considered for this study. Of the 100 respondents sampled for this study, twenty-six (26) are male representing $26 \%$ of the total sample, whilst seventy-four (74) are female representing $74 \%$ of the total sample. This shows the female dominance in this research and that responses of the views to be considered in this research is greatly that of female vendors. Also this could mean that the findings of this research are $74 \%$ likely to be the views of female vendors regarding the challenges associated with the handling of tomatoes by vendors in the Ho market.

Table 1 above shows the distribution of the respondents by age. Majority of the respondents considered for this study fall within the are range of 25-40, having a frequency of 68 and 
represented by $68 \%$ of the total vendors considered for this study, 22 of the vendors fall within the age range of 18-24 representing $22 \%$ of the total population and 9 of the vendors fall within the range of age 41 and above representing $9 \%$ of the total population.

Table 1 depicts the nationality of the vendors involved this study. Of the 100 vendors involved in the study, ninety-two (92) are Ghanaians representing 92\% of the vendors involved in the study, whilst seven (7) are Non-Ghanaians representing 7\%. This clearly shows that conclusions and findings that are drawn from this study concerning the challenges associated with the handling of tomatoes by vendors in the Ho market will largely be that of Ghanaians.

Table 1 depicts the level of education of respondents or vendors involved in this research. It can be seen that of the 100 vendors considered for this study, 12 of the vendors representing $12 \%$ of the total vendors do not have any formal education, 11 of the vendors representing $11 \%$ attained primary level, 53 of the vendors represented by $53 \%$ highest level is JHS/JSS, and finally those who attend middle school are represented by 23 vendors representing $23 \%$ with one of the vendors failing to indicate the level of education.

This clearly indicates from Table 1 that the findings of this research are $53 \%$ of the time likely to be the views of vendors who attained the JSS/JHS in terms of their level of education on challenges associated with the handling of tomatoes by vendors in the Ho market.

\subsection{Methods Used in Storage of Tomatoes}

Figure 1 displays how the tomatoes vendors store their goods or wares after closing from the market. The vendors who adopt the method of spreading their wares on the floor of the warehouse have a frequency of 33 represented by $33 \%$ of the total respondents, whilst those that adopts the method of storing in warehouse have a frequency of 38 are represented by $38.0 \%$. The vendors who adopt the method of freezing and covering their wares in market at places they sell have a frequency of 10 and 19 respondents respectively are represented by $10.0 \%$ and $19.0 \%$ respectively. 


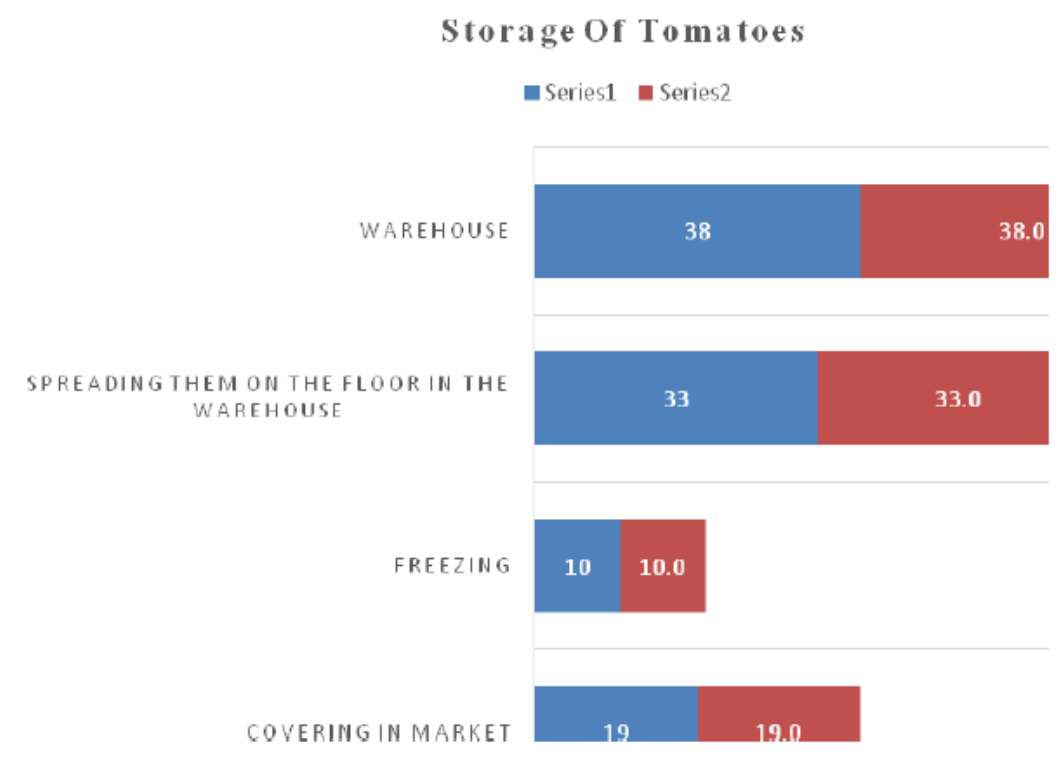

Figure 1. Storage of Tomatoes

Source: Fieldwork, May, 2018

From Figure 1 conclusion can be drawn that majority of vendors adopted the method of storing their wares or tomatoes in boxes in the warehouse as well as spreading them on the floor in the warehouse in the Ho market, which they view or see as a comfortable method for them to store their wares to enhance the growth of their business.

\subsection{Handling of Tomatoes by Vendors}

Figure 2 displays how vendors of tomatoes in the Ho market handle their wares or goods in the market in terms of displaying them. It can be observed that vendors of tomatoes in the Ho market who display their wares on trays are represented by $32 \%$, and on boxes are represented by $28 \%$, whilst those who handle theirs by displaying them on shelves are represented by $21 \%$ and those who handle theirs by displaying them on tables are represented by $15 \%$ and those who handle theirs by displaying them on wooden structures, cartons, crates and neatly arranging them in cans are represented by $1 \%$ respectively 


\section{Handling of Tomatoes}

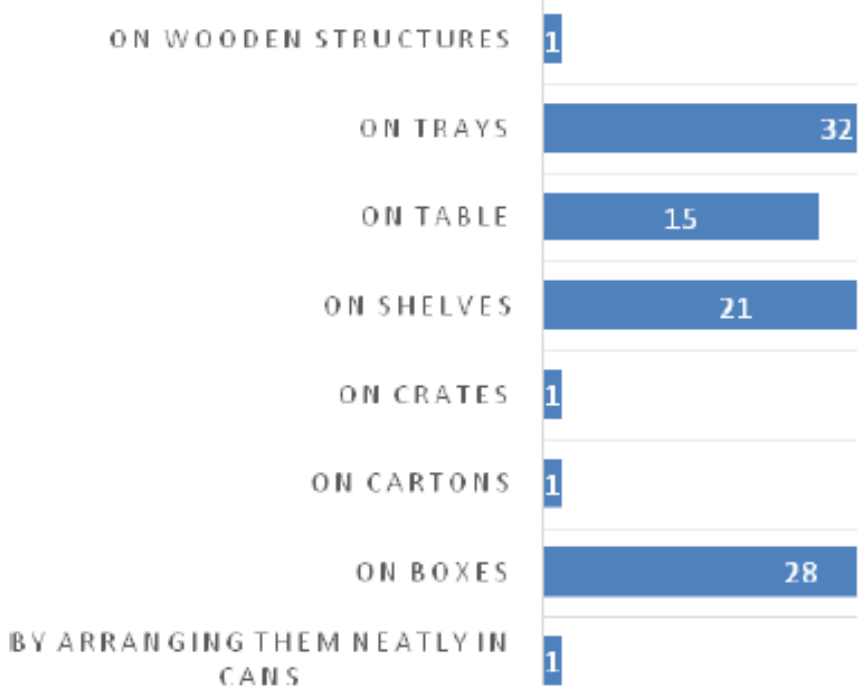

Figure 2. Handling of Tomatoes by Vendors

Source: Fieldwork, May, 2018

From Figure 2 conclusion can be drawn that $81 \%$ of vendors of tomatoes in the Ho market handle their wares or goods by displaying them on trays, on boxes and on Shelves in order to attract customers.

\subsection{Challenges Faced by the Respondents}

Figure 3 displays the challenges faced by vendors involved in this research. The vendors who are faced with the challenge of lack of ready market for their wares or goods are represented by $51 \%$ of the total respondents involved in this study, those who are faced with lack of storage facility are represented by $12 \%$, whilst those who are faced with the challenge of poor storage and pest attack are represented by $35 \%$ and $2 \%$ respectively. 


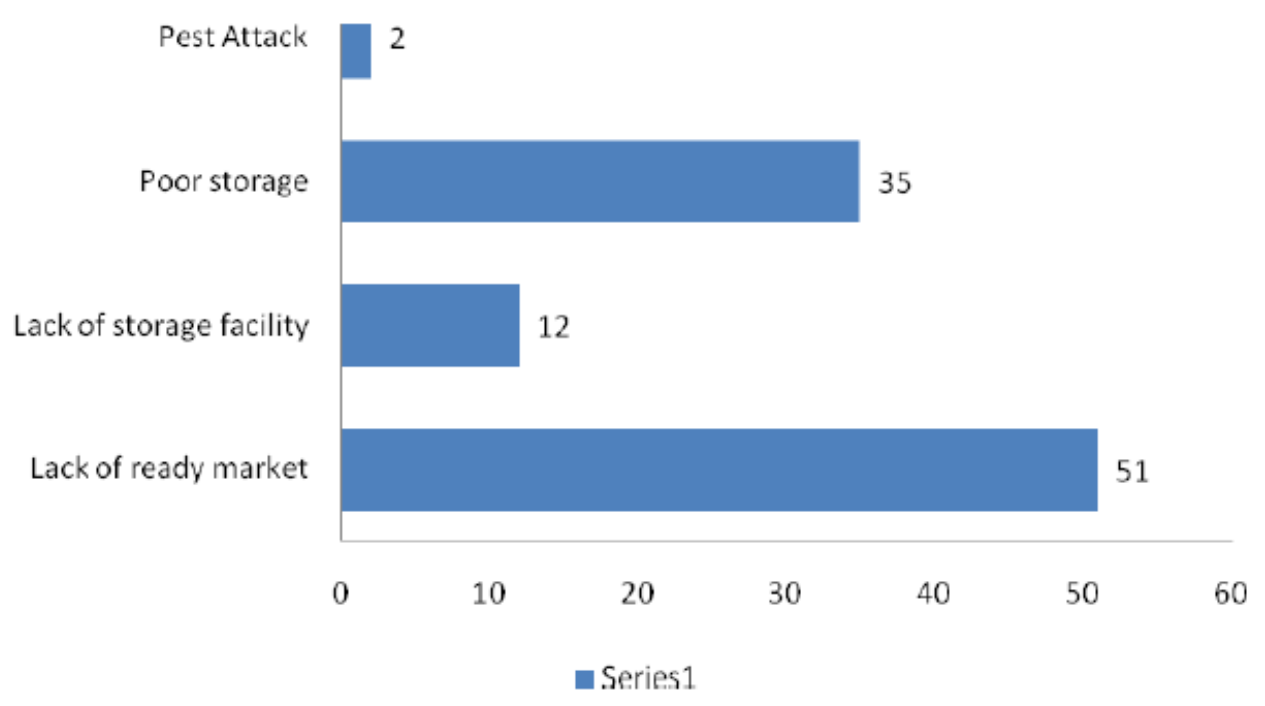

Figure 3. Challenges or Problems facing Vendors

Source: Fieldwork, May, 2018

From Figure 3 conclusion can be drawn that the greater challenge facing the vendors of tomatoes is the lack of ready market for their wares which heavily accounts for the spoilage of their wares and hence affects their business as well.

\section{Conclusions and Recommendations}

Extant literature reveals the challenges associated with the handling of tomatoes by vendors in the markets in Ghana. This study carried out a very comprehensive but integrative study putting up a very solid analysis on the responses of vendors involved in this study. The following conclusions were drawn from this comprehensive study;

Majority of vendors adopted the method of storing their wares or tomatoes in the warehouse in the Ho market, which they view or see as a comfortable, method for them to handle or store their wares to enhance the growth of their business.

The greater challenge facing the vendors of tomatoes is the lack ready market of their wares which heavily accounts for the spoilage of their wares and hence affects their business as well. Based on the finding and conclusions drawn the following recommendations were also made: The vendors should be educated more on the modern ways of handling and storage of their wares in order to enhance a long life span of their wares to ensure maximum enjoyment of the profitability of their wares.

The authorities in charge of the market should also put up storage equipment in the market for vendors to be able to store their wares properly to also enhance the life span of their wares as well. 


\section{Acknowledgement}

The authors are especially indebted to JosephineMawufemorArku, a student at the Department of Agro Enterprise Development of the Faculty of Applied Sciences and Technology, Ho Technical University, Ho Ghana.The authors are also grateful to the respondent (Tomatoes sellers at the Ho Central Market) and the anonymous reviewers who reviewed the paper.

\section{References}

Alam, T. T. (2007). Stewart Postharvest Review, Packaging and storage of tomato puree and paste. Stewart Postharvest Solutions.

Aminu, A. (2009). Framework for Agricultural Market Analysis: Theories and Application. Zaria: Ahmadu Bello University Press Limited.

Bani, R. J. (2006). Postharvest Losses of Tomatoes in Transit. Agric Mech Asia Afr Lat Am, 84-86.

Beecher, B. R. (1998). Nutrient content of tomatoes and tomato products. US: National Centre for Boitechnology Information. https://doi.org/10.3181/00379727-218-44282a

Cofie, O. V. (2003.). Contribution of urban and periurban agriculture to food security in Sub-Saharan Africa. Paper presented at the Africa Day.

Dixie, G. (2005). Horticultural Marketing, marketing extension guide 5. Rome, FAO.

Drechel, P. Q. (2010). Urban Agriculture and Changing Food Market. UEP Report Series, Prevention of Post-harvest food losses fruits, vegetables and root crops, a training manual (Vol.II). Rome: Food and Agricultu. 19-40 FAO .1989.

Fenni, S., Hammou, H., Astier, J., Bonnet, L., Karkeni, E., Couturier, C., Tourniaire, F., \& Landrier, J. F. (2017). Lycopene and tomato powder supplementation similarly inhibit high-fat diet induced obesity, inflammatory response, and associated metabolic disorders. Molecular nutrition \& food research, 61(9), 1601083. https://doi.org/10.1002/mnfr.201601083

Haruna, U., Sani, M. H., Danwanka, H. A., \& Adejo, E. (2012). Economic analysis of fresh tomato marketers in Bauchi metropolis of Bauchi state, Nigeria. Nigerian Journal of Agriculture, Food and Environment, 8(3), 1-8.

Hurst, W. D. (1993). American Water Purification Inc., Method for sanitizing food products. U.S. Patent 5, 227, 184.

Hussaini, H., Sani, A., \& Aliero, A. A. (2011). Volatile metabolites profiling to discriminate diseases of tomato fruits inoculated with three toxigenic fungal pathogens. Research in Biotechnology, 2(3).

Kitinoja, L. A., \& Gorny, I. (2009). Storage Practices and Structures. Postharvest Technology for Fruit \& Vegetable Produce Marketers, 1.1 - 20.6.

Ministry of Trade and Industry. (2007). [Online] Available: http://www.moti.gov.gh/ 
Obuobie, E., Ofori, D., Agodzo, S. K., \& Okrah, C. (2013). Groundwater potential for dry-season irrigation in north-eastern Ghana. Water international, 38(4), 433-448. https://doi.org/10.1080/02508060.2013.814212

Olukosi, J. O., \& Isitor, S. U. (2004). Introduction to Agricultural Marketing and Prices: Principles and Applications. Abuja: LivingBooks Series/G.U. Publications.

Orzolek, M. B. (2006). Tomato Production. Agricultural Alternatives Pub, 2-3.

Prasad, M. B. K., \& Ramanathan, A. L. (2008). Sedimentary nutrient dynamics in a tropical estuarine mangrove ecosystem. Estuarine, Coastal and Shelf Science, 80(1), 60-66.

https://doi.org/10.1016/j.ecss.2008.07.004

Singh, B. R. (2004). Constraints to Sustainable Crop Production in Semi Arid North West of Nigeria. The Nigerian Journal of Agricultural and Rural Management, 40- 62.

Tambo, J. A., \& Gbemu, A. (2010). Resource-use Efficiency in Tomato Production in the Dangme West District, Ghana. Zurich: Conference on International Research on Food Security and Natural Resource Managemant and Rural Development.

The oxford dictionary online service. (2011). [Online] Available: https://www.oed.com/

Van der Geer, J., Hanraads, J. A. J., \& Lupton R. A. (2000). The art of writing a scientific article. Journal of Scientific Communications, 163, 51-59

Van der Hoeven, R., Ronning, C., Giovannoni, J., Martin, G., \& Tanksley, S. (2002). Deductions about the number, organization, and evolution of genes in the tomato genome based on analysis of a large expressed sequence tag collection and selective genomic sequencing. The Plant Cell, 14(7), 1441-1456. https://doi.org/10.1105/tpc.010478

\section{Copyright Disclaimer}

Copyright for this article is retained by the author(s), with first publication rights granted to the journal.

This is an open-access article distributed under the terms and conditions of the Creative Commons Attribution license (http://creativecommons.org/licenses/by/4.0/). 